\title{
Psycho-Social Conception of National Identity and Collective Self-Esteem
} Bisera Mavrić*

\begin{abstract}
This paper deals with the phenomenon of national identity as well as with its connection to personal and collective self-esteem. National identity and associated phenomena have so far mainly been investigated as part of sociology, anthropology and political science, since psychology was less engaged in the issue. The national identity out of all kinds of social identity had the greatest influence on historical events. The consequences for the human race, through history, have been both positive and negative. Understanding the importance of this phenomenon has not only theoretical but also practical value for encouraging international tolerance. In recent years, national identity is a topic of interest for many researchers, mainly because of political events and frequent conflicts that are associated with ethnicity. This concept is especially important for Bosnian citizens who are still struggling with consequences from the recent conflicts in this multiethnic country. Most previous scientific papers explain their results within one of three theoretical frameworks: the social identity theory, theories of acculturation and cultural conflict, and the development of the theory of identity formation. Due to geopolitical changes in Europe, the growing interest of psychology to national identity is present, and thus the number of diverse research in this area. In many of them, there is a question about whether reinforces strong identification with the national group as a positive self-image and self-esteem contributes to it.
\end{abstract}

Key words: Psycho-Social, National Identity, Ethnicity, Collective SelfEsteem

\footnotetext{
* Corresponding author: Bisera Mavrić, Assistant Professor; Faculty of Arts and Social Sciences, International Univeristy of Sarajevo, e-mail: bmavric@ius.edu.ba
} 


\section{Introduction}

National identity colors numerous aspects of everyday life. Awareness of being a member of certain social category and emotional importance of this association builds the social identity. The process of social identification associated with group behavior involve: ethnocentrism, distinguishing into groups, conformity to group norms, appeal of own group and perception of another who is different. Social identification leads to these effects as well as to prejudice and stereotypes because it is connected with the social categorization (Francesco et al., 2002). Through the process of social categorization of people, things and phenomena in environment are placed in a certain categories based on their common heavy features. Often the information that people receive from the environment make it easier for human's knowledge of the world simplified. Categorization emphasizes similarities of people within the same category, their different diversity of members of other categories. The process of social categorization leads to the formation of stereotypes and prejudices, attitudes towards members of other categories or groups (Francesco et al., 2003). The fact that people identify with their social groups has become almost crucial to the explanation

\footnotetext{
Epiphany: Journal of Transdisciplinary Studies, Vol. 7. No. 1, (2014) (C) Faculty of Arts and Social Sciences
} 
of different intra and intergroup phenomena such as conflicts among different nations (Hui, 2004). The human need for self expression, the need for at least a certain aspect of self to be seen as constituted by a sense of collectivity and shared identity and not simply autonomous make it impossible to deny the reality of psycho-social conception of both national identity and collective self-esteem.

\section{National identity}

Groups with which people identify among the variety of them are certainly nations. Social identity stemmed from the feeling of belonging and identification with particular nation is called the national identity. National identity for an individual has the cognitive, emotional and motivational means of which it makes the subject interests of psychological research (Siber, 1998). The theory of social identity made by authors Tajfel and Turner (1986) is the first theory that fully engulfed the concept of social identity. This study explores its default settings, with the special focus on national identity as a kind of social identity. Within the theory I will explain the concepts of personal and collective self-esteem and observe their relationship with national

\footnotetext{
Epiphany: Journal of Transdisciplinary Studies, Vol. 7. No. 1, (2014) (c) Faculty of Arts and Social Sciences
} 
identity. Hopefully provided explanations should enlightened the complexity of Bosnian national identity as well. The people of Bosnia must understand their own position in order to behave and live in accordance with that position.

\section{Theories}

Social identity theory emerged in the mid-70s of the twentieth century and was made by authors Tajfel and Turner (1986). It is the first theory that systematically affected the concept of social identity and put it in the focus of social psychology. The theory deals with membership in the group, group processes and intergroup group relations (Tajfel and Turner 1989). Its basic premise is that the most only membership in a group is sufficient for providing the individual development of the feeling of belonging. According to Tajfel and Turner social identity is defined as the part of individuals sense of self that comes from the awareness that he is a member determined specific group (or groups), but also forms the emotional importance to him as affiliation (Tajfel, 1981, p. 255).

Social identity theory states that individual social identity is based on affiliation to specific groups that his social identity consists of aspects of their self-image which results from

\footnotetext{
Epiphany: Journal of Transdisciplinary Studies, Vol. 7. No. 1, (2014) () Faculty of Arts and Social Sciences
} 
those groups which human belongs to. Certain social categories within the group are excited about social identity (Francesco et al., 2003). Different authors will agree that the social identity of an individual depends on two processes: recognizing their similarities with members of their group and perceptions of different diversity in compared to members of other groups (Brewer, 1993, Calhoun 1994, Francesco et al., 2002). It is important to emphasize that an individual can have as many social identities as a group with which to identify. They vary in their importance that is salient for self-image depending on the situation in which the individual is located.

According to the theory of identity salience Stryker et al. (1994), an individual is more likely to identify with those groups that are prominent in their everyday life. In some social situation more pronounced will be the identity that involves relationships with several close people. Social identity theory emphasizes the differences between the personal and social identity. Personal identity is based on the idea of the uniqueness of each individual and its different diversity from all other people. It stems from the characteristics of the capabilities of the individual and his

\footnotetext{
Epiphany: Journal of Transdisciplinary Studies, Vol. 7. No. 1, (2014) @ Faculty of Arts and Social Sciences
} 
relationships with other people. Personal identity is based on the individual values, ideas, emotions, goals, and self perception. Social identity, as it is mentioned earlier, refers to the individual self perception as the member of group to which it belongs. However, belonging to a group and social identification are possible only when compared with groups that do not belong to. Social identity refers to the distinction from other groups. Social identity can be seen as a contradiction as well because it is difficult to understand how an individual can simultaneously feel different from each other but still similar to them. However, researches on real social groups have shown that personal and social identities are associated (S. Worchel et al., 1998). According to Tajfel and Turner (1986) social identity can be positive or negative depending on how the individual assesses their own social group, regardless of personal characteristics or achievements within the group. Social identity of an individual depends on his own evaluation of the groups and the perception of how others evaluate the group (S. Worchel et al., 1998). In case your own group is estimated as positive compared with other groups, social identity is positive (Mummendey, 1985, according

\footnotetext{
Epiphany: Journal of Transdisciplinary Studies, Vol. 7. No. 1, (2014) @ Faculty of Arts and Social Sciences
} 
to Francesco et al., 2003). The fundamental assumption of the theory of social identity is that membership in the group and feelings of belonging are contributing to the positive image of each individual.

\section{Positive and negative social identity}

Positive social identity provides a person the feeling of security, self-esteem, self-worth and affiliation. Future individual self-image will be based on own characteristics and the characteristics of the group to which they belong, so individual seeks group which is evaluated positively. It primarily makes the process of social comparison of own groups with other groups. The negative social identity refers to situation where individual's own group is estimated as negative compared with the comparative groups. It often happens that members of minority groups, in contact with a bigger majority group, develop low selfesteem, because they are perceived as belonging to an inferior group. Tajfel and Turner (1986) list some of ways in which the inferior group faces negative social identity. These are: social competence / members of a group trying to impartial way increase in the group and in the society. For example, members of ethnic

\footnotetext{
Epiphany: Journal of Transdisciplinary Studies, Vol. 7. No. 1, (2014) @) Faculty of Arts and Social Sciences
} 
minorities established political parties in order to participate in local government. Organizing different cultural happenings and events to the public present their cultural and ordinary drives. Individual mobility - people with negative social identity may discard and replace certain group as a group that poses better basis for the development of a positive social identity. Moreover, it is not possible with category boundaries involved, such as race or gender. Different strategy of social creativity: a) comparative neglect of the dimension in which the comparison unfavorable for inferior group and search for new dimension on which will be more favorable comparisons, b) the choice of less threatening will out group comparison. Inferior group does not slow with the dominant group than the minorities in a way when the outcome is advantageous. The consequence is the development of pride in the group. Discrimination and vilification of other groups to own a group of experienced as superior and better. Tajfel and Turner states that people, in order to achieve a positive social identity, perceived their own group, not only as positive, but as better than other groups. National identity from all kinds of social identity had the greatest impact and the historical events devices. The

\footnotetext{
Epiphany: Journal of Transdisciplinary Studies, Vol. 7. No. 1, (2014) @ Faculty of Arts and Social Sciences
} 
consequences for humanity, throughout history, have been both positive and negative. Understanding the importance of this phenomenon has not only theoretical but also practical value necessary to encourage international tolerance. In recent years, national identity is the subject of interest of many researchers primarily because of political developments and frequent conflicts that are associated with a national belongingness (Siber, 1998).

\section{Psychological aspect of a nation}

Psychological aspect of a nation is defined as a feeling of belonging, community, and as a system of attitudes towards their own ethnic group. National feeling is a feeling of belonging that is formed within a certain social group. However, besides the national feeling of subjective categories it largely depends on the behavior of others towards us and on their evaluation of our national identification. National identity and associated phenomena have so far mainly been investigated as part of sociology, anthropology and political science, and psychology to a lesser degree. In recent years, due to geopolitical changes in Europe, growing interest in psychology to national identity has been present. Most previous works

\footnotetext{
Epiphany: Journal of Transdisciplinary Studies, Vol. 7. No. 1, (2014) (c) Faculty of Arts and Social Sciences
} 
explaining their results within one of three theoretical frameworks: the theory of social identity theory of acculturation and cultural conflict, and developmental theories of identity formation (Phinney, 1990). According to social identity theory membership in the group in the individual arises the feeling of belonging and built the positive social identity. An individual with their national groups share common beliefs, attitudes, values, ordinary drivers, language and religion.

If we take as an example the fusion of religious and ethnic national identity in Bosnia and Herzegovina the distinction between "us" from "them" leads to understanding of national identity, which is constantly changing and is created through interaction and retreat borders to other groups. Different religious groups do not accept the same national identity. Subjective identification of the individual with the group is essential for national identity but also the recognition concerned group of by external members (Hui, 2004). Many studies raised the question if the strong identification with a national group contributes towards a positive image of yourself and higher self-esteem. When the dominant group in society underestimates or demeans a minority

\footnotetext{
Epiphany: Journal of Transdisciplinary Studies, Vol. 7. No. 1, (2014) @ Faculty of Arts and Social Sciences
} 
group member of minority groups can develop negative social identity (Phinney, 1990). Contact with bigger majority group of members and minority groups can get to the development of low self-esteem because they are perceived as members of inferior groups. There are several different ways to "defense" the inferior group. Tajfel and Turner (1986) say that the identification with their own group is mostly pronounced when the boundaries between into tight groups, status refers unstable and when differences are perceived as illegitimate (Ellemers et al 1988). According to Phinney (1990), the identification of the two different groups can occur in people under the influence of two or more cultures. It may adversely affect the development of the national identity of members of minority groups due to a conflict of values, attitudes and norms behavior between them and most majority groups. Impact of two cultures or more cultures in some situations can have positive effects on the cultural identity of the individual. It is the most common to happen when cultures are compatible, similar in terms of norms, values and attitudes. Acculturation model emphasizes that the national identity can speak just in case when there is prolonged contact between the

\footnotetext{
Epiphany: Journal of Transdisciplinary Studies, Vol. 7. No. 1, (2014) (c Faculty of Arts and Social Sciences
} 
two or more ethnical group, which then let a broader analysis of the changes in cultural attitudes, values and behavior which is the case in our country.

\section{Developmental theories}

Developmental theories are the third in the group of theories of national identity. According to them national identity is considered to be dynamic and changing anyone in time and context. Based on the theory of development of Erikson egoidentity of individual assumes a long process of research and experimentation (Fulgosi, 1983). Development of national identity is seen as a process where an individual examination of the role of national identity in their lives. The process consists of three phases. The first phase is diffused, unexplored national identity. According to the model, at this stage there are adolescents and those adults who have not been exposed review their own national identity. As quoted in Phinney (1990) key term period for the formation of national identity is considered the transition from primary to secondary school. Some authors believe that at this stage of minorities occurs preferences the dominant culture. However, it is not necessarily so because it is possible that young people were not interested in national issues

\footnotetext{
194

Epiphany: Journal of Transdisciplinary Studies, Vol. 7. No. 1, (2014) (C) Faculty of Arts and Social Sciences
} 
and not thinking about them. It is also possible that parents take positive national attitudes and therefore do not show a preference to the biggest group. Research of own national identity is the result of experience that has generated awareness of the individual of belonging to a certain group. This process involves various activities such as reading about ethnicity, participation in cultural events etc. For minorities this process can include both acceptance and rejection of the dominant culture. According to the process model, the development of national identity results in a better understanding of their nationality in the internalization of national identity. Because of different personal and historical experiences internalized national identity has different apparent means of the different individuals and groups.

\section{Internalized national identity}

Internalized national identity does not necessarily imply a high degree of ethnicity but includes exposure of an individual who may be aware of their national affiliation. Phinney (1990) states that minority at this stage faces supporting with two fundamental problems: a) cultural difference between their own and the dominant group and b) lower to their own group society.

\footnotetext{
Epiphany: Journal of Transdisciplinary Studies, Vol. 7. No. 1, (2014) @ Faculty of Arts and Social Sciences
} 
According to the model Phinney, the adoption of national identity does not necessarily end of the process of its development. The model emphasizes the dynamic aspect of adoption of national identity. Phinney (1990) says that, when it comes to the dominant group, phase changes slower than at minority groups, because there is a longer stay at the stage of the diffusion of national identity. Members of the dominant group simply take the value of their groups and have less need for research of their own national identity as resulting in little change of phase of national identity. Deaux (1996) states that positive attitudes are the most commonly expressed and explored through positive affective reactions as pride and satisfaction and acceptance in regard of strengthening of their own group. The lack of positive attitudes and/or express negative attitudes towards their own national group can be seen as a denial of its own national identity. Negative attitudes can manifest itself as a desire for it to be become member of another ethnic group (Phinney, 1990). According to the International Social Survey Programme (ISSP) 22 European countries showed interesting results. A higher level of national pride show that participants have a strong feeling of national belonging that is

\footnotetext{
Epiphany: Journal of Transdisciplinary Studies, Vol. 7. No. 1, (2014) (C) Faculty of Arts and Social Sciences
} 
feeling the case "Close" to his country. Older and less educated participants show bigger national pride, while the difference based on gender was not determined (Orcs and Kamen, 1998). It also included exposure to the work and life of their own ethnic group and referred to how individuals involved in maintaining the tradition and culture. The research used the most common indicators included exposure to: the use of national language, the way of friendships and intimate relationships, i.e., whether it is for them belonging to the same ethnic important, how is group affiliation determined, particular religion and its practice, participation in activities and the formation of social and national institutions (homeland, clubs, societies), it also included exposure to political activities for the betterment of their own national group, the selection of housing with respect to the national affiliation, the fostering of national values, interest in the country of origin, and knowledge of national history and culture (Phinney, 1990). Rot and Havelka (by Siber, 1998) assume that there are five types of national attachment: First is the national attachment, characterized by a distinct awareness of belonging to their own nation, the only score that affiliation is important and means

\footnotetext{
Epiphany: Journal of Transdisciplinary Studies, Vol. 7. No. 1, (2014) @ Faculty of Arts and Social Sciences
} 
significant, and contempt of other nations. The authors believe that this form of national attachment corresponding terms in the literature signifies concepts as ethnocentrism, nationalism or national chauvinism. Furthermore, they are talking about prominent national attachment that involves patriotism and a certain national level of acceptance and strengthening of the existence of other national affiliation.

\section{Conclusion}

Multiple national attachments are a form of internationalism that is characterized by feelings such as loyalty to their own nation, but also the desire for international cooperation and understanding. Loyalty is primarily reflected by mankind, according to what is judged human, valuable and advanced for all nations and peoples. Prominent international ties are characterized by attachment to the human community and strive to overcome narrow national interests. This would be the identifying sign of cosmopolitanism. The absence of national attachment or individualism or lack of attachment to any nation or the national feeling is considered unnecessary and harmful. A series of studies

\footnotetext{
Epiphany: Journal of Transdisciplinary Studies, Vol. 7. No. 1, (2014) (c) Faculty of Arts and Social Sciences
} 
were conducted in order to verify this theoretical model. In this scope, if Bosnia is a name for any kind of identity, its content is not the mathematical sum of nations or national cultures. Its content lies in permanent cultural interaction. The name Bosnian is not a term for a national order, or only a regional or territorial one. It is a name for the process of civilization that lasts for a millennium, through historical changes and political adversities practiced with vitality by all. In this ongoing process of interaction special identities retained exposing themselves to the continuous culture change.

\section{References}

Bray, B. M. (2001). The influence of academic achievement on a college student's self-esteem.

http://clearinghouse.mwsc.edu/manuscripts/225.asp.

Brewer, M. B. (1993). Social Identity, distinctiveness, and in-group homogeneity. Social Cognition, Vol. 11, No. 1, pp. 150-164.

Calhoun, C. (1994). Social Theory and the politics of identity, in Calhoun, C. (ed.) Social Theory and the Politics of Identity. Cambridge Mass: Blackwell Publishers.

Cinnirella, M. (1997). Towards a European identity, Interactions between the national and European social identities manifested by university students in Britain and Italy. British Journal of Social Psychology, $36,1,19-31$.

Corkalo, D. i Kamenov, Ž. (1998) Nacionalni identitet $i$ medjunacionalna tolerancija, Izvještaj s VIII. Ljetne psihologijske škole, Odsjek za psihologiju Filozofskog fakulteta u Zagrebu.

Deaux, K. (1996). Social Identitety in: Social Psychology Handbook of Basic Principles, Higgins, E. T. \& Kruglanski, A. W. (Eds.), Guilford Press. 
Ellemers, N., Van Knippenberg, A., de Vries, N. \& Wilke, H. (1988). Social identification and permeability of group boundaries. European Journal of Social Psychology, No. 18, pp. 497-513.

Franceško, M., Kodžopeljic, J., Majstorovic, N. i Mihic, V. (2002). Aspekti Evropskog identiteta operacionalizovani skalom EUROID2002, Licnost u višekulturnom društvu, Vol. 4, str. 105-114.

Forum Bosnae Journal, Reconstruction and Deconstruction, IFB , 2007.

Fulgosi, A. (1983). Psihologija licnosti: teorije i istraživanja, Školska knjiga, Zagreb.

Jelic, M. (2003). Provjera postavki teorije socijalnog identiteta na etnickim grupama, Magistarski rad, Filozofski fakultet u Zagrebu.

International Forum Bosnia, www. mfb.ba.

Lackovic- Grgin K. (1994) Samopoimanje mladih, Naklada Slap, Jastrebarsko.

Luhtanen, R. i Crocker, J. (1992). A Collective Self-Esteem Scale: SelfEvaluation of One's Social Identity. Personality and Social Psychology Bulletin, Vol. 18, No.3, 302-318.

Miloševic. J. (2003). Jedan pokušaj klasifikacije teorijskih razmatranja nacionalnog identiteta, Psihologija, Vol. 36 (2).

Phinney, J. S. (1990). Ethnic identity in adolescents and adults: review of research. Psychological Bulletin, No. 108, pp. 499-514.

Rosenberg, M. (1965). Society and Adolescent Self-Image, Princeton, New Yersey, Princeton University Press.

Šiber, I. (1988). Psihologijski aspekti medjunacionalnih odnosa. Zagreb: Kulturno prosvjetni Sabor Hrvatske.

Šiber, I. (1998). Osnove politicke psihologije, Politika kultura, Zagreb.

Tajfel, H. (1981). Human groups and social categories: Studies in Social Psychology. Cambridge, UK: Cambridge University Press

Tajfel, H. i Turner, J. C. (1986). The Social Identity Theory of Intergroup Conflict. The Social Psychology of Intergroup Relations. (pp. 33-47). Monterey, CA: Brooks/Cole.

Weissbrod, L. (1983). Religion as national identity in secular society, Review of Religious Research, Vol. 24, No. 3, pp. 188 - 205. 